\title{
Study on national activities and funding opportunities of furthering education programs for unemployed academics
}

\author{
Susanne Rahner ${ }^{1,}{ }^{*}$, Ilona Winter ${ }^{1}$ Michael Hartmann ${ }^{2}$, Frank Wittich ${ }^{2}$, Aleksandra \\ Kasztelewicz ${ }^{3}$, Barbara Tomaszewska ${ }^{3}$, Leszek Pająk ${ }^{3}$, Marta Dendys ${ }^{3}$, Agnieszka \\ Operacz ${ }^{4}$, Marta Mraz $^{5}$, Stelian Nistor ${ }^{6}$ \\ ${ }^{1}$ Umweltbüro für Berlin-Brandenburg e.V., Berlin, Germany \\ ${ }^{2} \mathrm{SRH}$ Hochschule Berlin, Berlin, Germany \\ ${ }^{3}$ Mineral Energy Economy Research Institute, Polish Academy of Sciences, Cracow, Poland \\ ${ }^{4}$ University of Agriculture, Cracow, Poland \\ ${ }^{5}$ Polip Youth Association, Szekszárd, Hungary \\ ${ }^{6}$ University of Oradea, Oradea, Romania
}

\begin{abstract}
The joint German - Hungarian - Polish - Romanian Project EUBILD-UNAKLIM 2016-1-DE02-KA204-003254 in the ERASMUS + Scheme KA2 (Strategic Partnerships) designs an international adult-learning furthering education course. It took place in the participating countries Germany, Hungary, Poland and Romania. Environmental and cross-sector topics were addressed. A "green" job search and a questionnaire among employers, financing and educational institutions and NGOs was performed across the partner countries in 2017. The objectives were to find differences in employers' opinions on staff skills and the training topics provided by the furthering education organizations. In case differences were found, the course could close these gaps and will be adapted to the employers' needs, bringing more course participants into employment. Statistical evaluation compared countries, institution types, employers and furthering educationand financing institutions. The results were visualized in pie charts, histograms, and - where applicable - trend lines. Preliminary results show clear ranking of the new "green" job categories with differences in countries and institutions. The questionnaire results show differences in topic selection between employers and furthering education bodies. The results form the base for the course curriculum design closing the gaps between employers' expectations for "green" job topics and existing training curricula.
\end{abstract}

Keywords: furthering education, adult learning, environmental topics, green jobs, statistics

*Corresponding author: info@yggdrasil-dr-rahner.de 


\section{Introduction}

In view of climate change and responding to political, economic and ecological challenges the number of "green" jobs is expected to rise. This will have an impact on education and training, and also on the long-life learning processes. In the joint German - Hungarian Polish - Romanian project EUBILD-UNAKLIM 2016-1-DE02-KA204-003254 in the ERASMUS+ Scheme KA2 on Strategic Partnerships, five partners work on an international adult-learning furthering education course concept. Designed to take place in the four participating countries with training languages in the four national languages and in English. The course implementation is planned for the years $2019-2020$.

The goal is a course with opportunities to attend in different countries, with online learning platforms, and internship and many practical, economy-driven activities and aspects.

Target groups are unemployed adults with an academic background, looking for new avenues in their careers, university drop-outs, migrants, single parents with children and other less privileged groups having difficulties and barriers to enter the employment market.

The topics are "green job" and environmental issues, i.e. nature protection, nature reserve management, European Fauna-Flora-Habitat (FFH) management, geology, water, emissions, sustainable energy, but also software topics such as Geographical Information Systems (GIS), and cross-sector topics such as project management, applied project work, team work, self-management and international environments. The course will take 6 months of theoretical input, followed by an internship period of 3 months in a country other than the one of residence.

The outputs are: a study on green jobs, a questionnaire on skill expectations for employees and course participants, a curriculum, training letter and e-learning platform, finally an implementation concept for the first course.

\section{Definition of the "Green Jobs"}

Green jobs are decent jobs that contribute to preserve or restore the environment, be they in traditional sectors such as manufacturing and construction, or in new, emerging green sectors such as renewable energy and energy efficiency [1-3].

The scope of Green jobs is:

- Improve energy and raw materials efficiency;

- Limit greenhouse gas emissions;

- Minimise waste and pollution;

- Protect and restore ecosystems;

- Support adaptation to the effects of climate change.

At the enterprise level, green jobs can produce goods or provide services that benefit the environment, for example green buildings or clean transportation. However, these green outputs (products and services) are not always based on green production processes and technologies. Therefore green jobs can also be distinguished by their contributions to more environmentally friendly processes. For example, green jobs can reduce water consumption or improve recycling systems. Green jobs defined through production processes do not necessarily produce environmental goods or services. Green jobs, are classified as, "jobs in business that produce goods or services that benefit the environment or conserve natural resources" or "jobs in which workers' duties involve making their establishment's production processes more environmentally friendly or use fewer natural resources" [1]. The Bureau of Labor Statistics, Washington [1] categorizes green jobs into: Water conservation, Sustainable forestry, Biofuels, Geothermal energy, Environmental Remediation, Sustainability, Energy auditors, Recycling, Electric Vehicles, Solar power, and Wind energy. 
Green jobs or green-collared jobs are, according to the United Nations Environment Program [4], "work in agricultural, manufacturing, research and development (R\&D), administrative, and service activities that contribute(s) substantially to preserving or restoring environmental quality. Specifically, but not exclusively, this includes jobs that help to protect ecosystems and biodiversity; reduce energy, materials, and water consumption through high efficiency strategies; decarbonize the economy; and minimize or altogether avoid generation of all forms of waste and pollution. The environmental sector has the dual benefit of mitigating environmental challenges as well as helping economic growth.

The definitions include jobs which seek to use or develop renewable forms of energy (i.e. wind, hydropower, geothermal, wind, landfill gas and municipal solid waste) as well as increase their efficiency. Under the green jobs domain education, training, and public awareness are also included. These jobs seek to enforce regulations, support education, and increase public influence for the benefit of the environment.

In 2008 the United Nations Environment Programme (UNEP) [4], the International Labour Organization ILO [5], the International Trade Union Confederation ITUC [6] and the International Employers Organization IEO [7] jointly launched the Green Jobs Initiative. The purpose is to bring a just transition to a green economy by providing space for workers, employers, and governments to negotiate on policy effective in providing equitable opportunity to green jobs.

\section{Green Job Search in the Partner Countries}

\subsection{Green Jobs in Germany}

The total 32 job portals were searched and about 16,778 green job ads were identified. Since an estimated of $10 \%$ of duplicates were identified, around 15,100 genuine job advertisements were identified. This equates to $2.29 \%$ of the annual total job offerings reported by the German Federal Statistics office. The main portal for green jobs is www.greenjobs.de. The research was performed between November 2016 and May 2017.

\subsection{Green Jobs in Hungary}

Green jobs is not a priority in job advertisements, it is difficult to decide what a green job is: any job done in a green economy (e.g. a driver) or a job is not a green economy, but it can be classified as a green job (e.g. environmental protection worker). The Hungarian research was conducted on the www.profession.hu website between 1 March and 30 April 2017, for 60 days, where the full offer will be published, and from 1 to 30 June 2017. Bids on a green jobs portal were search. According to the Ministry of National Economy, there is no reports -on green jobs at the national level. The green topic is not big enough to get into larger specifications or to make separate statistics, or to get attention. There is an aspiration to strike this strategy - but at the current labour market there is no focus on it. There is a tendency to increase in this area. The size of Hungarian job market is not comparable with the larger EU countries'.

\subsection{Green Jobs in Poland}

In Polish market the largest job portal is www.pracuj.pl, but only one portal (regularly updated), specialised in green jobs was found - portal www.teraz-srodowisko.pl. The total of 241 offers in the green topics were found in this portal between February and April 2017. Currently among all green job offers the most numerous were in the environmental 
management $(21 \%)$ energy sector $(20 \%)$, in industry and engineering sector $(12 \%)$ and business management $(11 \%)$. At present, the greatest demand on the market is on: environmental specialists (14 offers) and energy auditors (10 offers).

Preliminary conclusions:

- In Poland, development of the green job sector is slower than for e.g. in Germany;

- In Germany, thanks to the implementation of a series of activation and support measures, about 380,000 green jobs have already been generated. In Poland, this type of statistics has not been started yet, and the modernisation of the energy sector is proceeding very slowly (lack of support for pro-consumer and civic energy) [8];

- Lack of systematic analysis of the sectors and industries (indicators -> identify and remove barriers);

- No official definition of "green jobs", "green economy", "green sectors in the economy" in Poland.

\subsection{Green Jobs in Romania}

The market share has been taken into consideration, the number of registered companies, posted announces in the period of 60 days, number of registered CV (Curriculum Vitae) on the database and the monthly traffic of the website. The most important (negative) element is that there is no specific "green job" position mentioned on the top ranking. The search was made using two levels of search: first the search of national database and as second level the search of the offer for each county. At county level (there are 42 counties in Romania) the job offer is structured in two main directions. The first direction is represented by job offers posted at the website of County Agency of Labour Force Occupation, which are state companies, the main activity is collecting offers from different companies (state or private). The second direction is represented by job offers from private media (online, media a.s.o.) which also provide job offers from different economy sectors [9]. The total of 61 databases in Romania and abroad were searched. The search was performed between November 2016 and February 2017.

\section{Questionnaire results on skill and knowledge expectations of potential employees}

An online questionnaire was sent out in five languages: German, Hungarian, Polish, Romanian and in English. It was kept open from November 2016 until March 2017. A total of 1,866 targets were addressed, 400 in each consortium country was the goal. The total of 112 questions were asked in total, thereof 20 open questions, 23 closed questions (only "yes" and "no" as answer possible) and 69 questions that could be assessed by " 1 = totally unimportant" until " $6=$ very important". The questionnaire was supported by structured interviews, five in each partner country. The structured interviews results were inserted into the statistics. The reflux quota was planned to be above $10 \%$. We sent out several reminders, had lots of telephone calls, individual emails and also other activities throughout our networks. As a result we nearly achieved the total of $10 \%$. Hungary had the best results; probably their networks are more efficient than the others. Table 1 shows the reflux results. 
Table 1. Reflux results of the questionnaire in the countries and categories.

\begin{tabular}{|c|c|c|c|c|c|}
\hline Reflux & Germany & Poland & Rumania & Hungary & Total \\
\hline \multirow{2}{*}{ Employers } & 45 & 9 & 5 & 25 & 84 \\
\cline { 2 - 6 } & $9.57 \%$ & $4.54 \%$ & $3.67 \%$ & $13.03 \%$ & $8.9 \%$ \\
\hline $\begin{array}{c}\text { Furthering education and } \\
\text { financing bodies }\end{array}$ & 15 & 31 & 10 & 23 & 79 \\
\cline { 2 - 6 } & $8.02 \%$ & $14.02 \%$ & $4.54 \%$ & $9.78 \%$ & $9.17 \%$ \\
\hline \multirow{2}{*}{ Total } & 60 & 40 & 15 & 48 & 163 \\
\cline { 2 - 6 } & $9.13 \%$ & $9.54 \%$ & $4.16 \%$ & $11.32 \%$ & $8.73 \%$ \\
\hline
\end{tabular}

\subsection{Statistical evaluation}

The $84 / 70$ questionnaires were completed. In some questions were empty answers, or people responded with "n.a=no answer", usually less than 4\% "n.a." were given, in some delicate questions with high uncertainty, however, the rate rose up to $50 \%$. Only the fully answered questions were statistically processed. In order to give quality estimates of the answers, the "n.a."-percentage is also given. We compared the absolute numbers, and the total percentages. However, countries with high feedback (Hungary, Germany and Poland) produce a high weighting for their answers and subsequently distort the comparison towards the German, Hungarian and Polish facts. In order to avoid this, internal country comparisons were carried out in addition. However, it should be kept in mind, that Germany has an absolute reflux of 45/15, Hungary 25/23, Poland 9/31 and Romania 5/10. The questions were categorized into countries and into institutional forms (i.e. private companies, public service, ministries, NGO, chambers, also Job centers). There were not enough data to categorize into countries and organizations. Comparisons of employers, furthering education institutions and institutions financing the furthering educations were performed.

It were performed state-of-the-art statistical data, i.e. average, mean, standard deviation, confidence interval at $95 \%$, confidence minimum and maximum, skewness. It was visualized by pie charts, histograms, $\mathrm{X} / \mathrm{Y}$ diagrams. In the case of the open questions, answers have been translated to English and categorized.

\subsection{Results}

In the employer respondents $33 \%$ were private enterprises, $30 \%$ NGOs, each $14 \%$ trade associations and public services. Of minor percentage were chambers, employers' associations and training and research institutions with 2-4\%. The financing body respondents had $23 \%$ of NGOs, 39\%, furthering education and financing institutions. Unemployment offices, municipal bodies and other institutions each $11 \%$, and some had $1 \%$ (see Figures 1a and 1b). The employers were generally more than 10 years on the market. Romania here is the exception; here responded mainly young enterprises. The number of staff members among the employer respondents is significantly lower than of the financing and furthering education respondents. This phenomenon is visible across all countries. Most respondents were small and medium enterprises (SME) according to the EU-Definition (see Figure 2). 

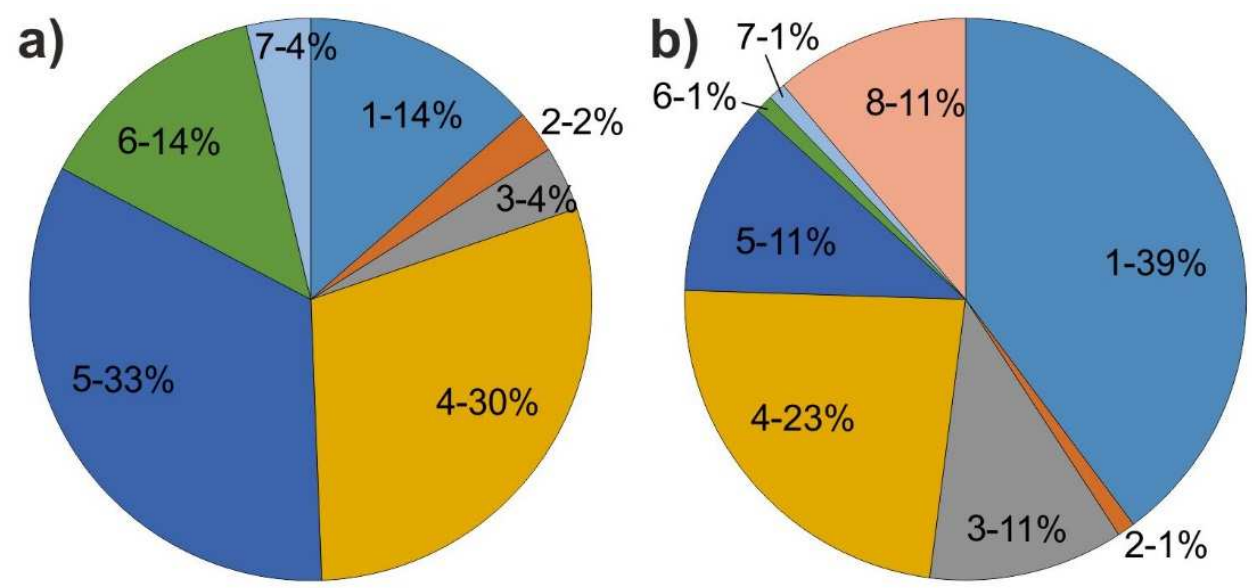

Fig. 1. a) Different institutions among the Employers (all countries). 1: Trade and association, 2: Chamber of Industry and Commerce, 3: Employers' Association, 4: NPO/NGO, 5: Private Enterprise, 6: Public Service Authority/Ministry, 7: Training and Research Institution. b) Different institutions among the furthering institutions and financing bodies (all countries). 1: Furthering education /Educational Institution, 2: Ministries/ Governmental Authority, 3: Municipal, communal, regional public institution, 4: NPO/ NGO, 5: Other, 6: Programme initiating institution, 7: Public Service/ Public Administration, 8: Unemployed office.

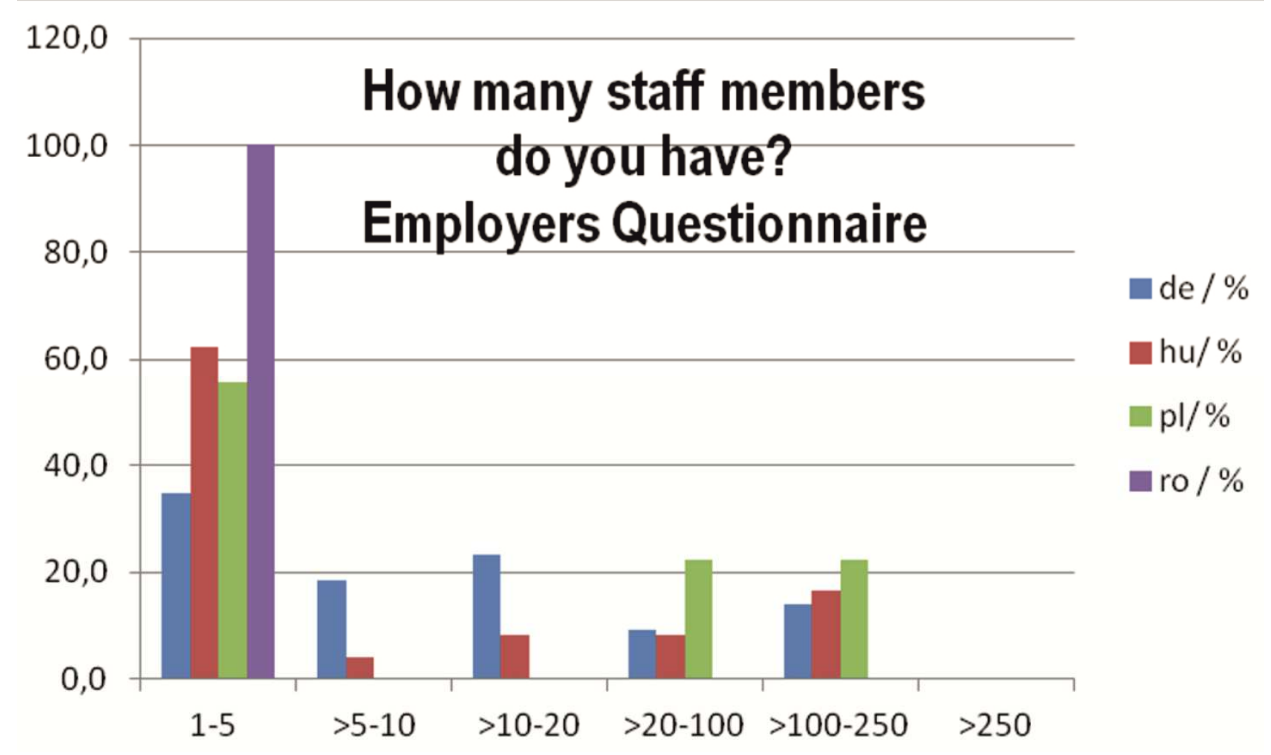

Fig. 2. Number of staff members for employers.

\subsection{Hypotheses}

Before sending out the questionnaire to obtain data, hypotheses was brainstormed to prove or reject (= Null-Hypotheses). The results are compiled in Figure 3. 


\begin{tabular}{|c|c|c|}
\hline Hypothesis 1: & $\begin{array}{l}\text { Larger Institutions need more Qualification or new Staff in } \\
\text { Environmental topics. }\end{array}$ & No correlation \\
\hline Hypothesis 2: & Everyone needs qualification in environmental topics. & Statistical indices \\
\hline Hypothesis 3: & $\begin{array}{l}\text { The duration on the market does not correlate with more } \\
\text { qualification / recruitment of personnel. }\end{array}$ & No correlation \\
\hline Hypothesis 4.1: & $\begin{array}{l}\text { In recruiting personnel, also non-formal certificates are } \\
\text { accepted. }\end{array}$ & Statistical indices \\
\hline Hypothesis 4.2: & $\begin{array}{l}\text { Smaller institutions accept non-formal certificates better than } \\
\text { large institutions. }\end{array}$ & $\begin{array}{l}\text { Statistical indices, } \\
\text { correlations, } \\
\text { Histogrammes }\end{array}$ \\
\hline Hypothesis 5: & $\begin{array}{l}\text { At institutions of all sizes, environmental topics play a large } \\
\text { role. }\end{array}$ & $\begin{array}{l}\text { Statistical indices, } \\
\text { correlations, } \\
\text { Histograms }\end{array}$ \\
\hline Hypothesis 6: & $\begin{array}{l}\text { The larger an institution, the more unimportant become cross- } \\
\text { sectoral topics. }\end{array}$ & $\begin{array}{l}\text { Statistical indices, } \\
\text { correlations, } \\
\text { Histograms }\end{array}$ \\
\hline Hypothesis 7.1: & $\begin{array}{l}\text { The larger the organisation, the more important is the Topic: } \\
\text { "Project Management". }\end{array}$ & $\begin{array}{l}\text { No correlation, } \\
\text { Histograms }\end{array}$ \\
\hline Hypothesis 7.2: & $\begin{array}{l}\text { The larger the organisation, the more important is the Topic: } \\
\text { "Team Work". }\end{array}$ & $\begin{array}{l}\text { No correlation, } \\
\text { Histograms }\end{array}$ \\
\hline Hypothesie 7.3: & The larger the organisation, the more important are IT-Skills & $\begin{array}{l}\text { No correlation, } \\
\text { Histograms }\end{array}$ \\
\hline Hypothesis 7.4: & $\begin{array}{l}\text { The larger the organisation, the more important is the Topic: } \\
\text { "Proposal Writing". }\end{array}$ & $\begin{array}{l}\text { Negative correlation, } \\
\text { Histograms, Trend }\end{array}$ \\
\hline Hypothesis 8: & $\begin{array}{l}\text { The larger the organisation, the more they need "Green" } \\
\text { Knowledge. }\end{array}$ & $\begin{array}{l}\text { correlations, } \\
\text { Histograms } \\
1 \text { outlier }\end{array}$ \\
\hline Hypothesis 9: & $\begin{array}{l}\text { Furthering education topics in the environmental frame are not } \\
\text { known. }\end{array}$ & Statistical indices \\
\hline Hypothesis 10: & $\begin{array}{l}\text { The larger the organisation the more important are ! } \\
\text { environmental topics. }\end{array}$ & $\begin{array}{l}\text { Negative correlation, } \\
\text { Histograms, Trend }\end{array}$ \\
\hline
\end{tabular}

Fig. 3. Hypotheses situation after the statistical evaluation.

From the total of 14 hypotheses, 10 were rejected, one was indifferent and 4 were proved. The proved hypotheses:

- Smaller institutions accept non-formal certificates better than large institutions (No. 4.2). It was proved by all statistical indices, histograms and correlations.

- At institution of all sizes environmental topics play a large role (No. 5). It was proved by all statistical indices, histograms and correlations.

- The larger the organisation, the more they need "Green" knowledge (No. 8). It was proved by all statistical indices, histograms and correlations. There was one outlier.

- Furthering education topics in the environmental frame are not known (No. 9). It was proved by the statistical indices.

The following hypotheses proved the contrary. So it was proved that:

- The smaller the institution, the more important is the topic: "Proposal Writing". It was proved by the negative correlation of the Null-Hypothesis, the statistical indices and the histograms.

- The smaller the organisation, the more important are environmental topics. It was proved by negative correlations of the Null-Hypothesis, histograms and a trend line. 


\subsection{Gaps in Employers and Furthering education / Financing institutions expectations}

The questionnaire had been designed in such a way that it should mirror the questions for employers and the furthering education/financing bodies as exactly as possible. It was assumed to prove if the employers' wishes and expectations for staff skills and of the furthering education courses offers of the furthering education bodies. The aim of the work is to provide a curriculum as closely as possible adapted to the commercial market. We consider that thus provide an uptake of our course participants by the labour market at its best possible rate. The analysis showed many gaps in these aspects (Fig. 4).

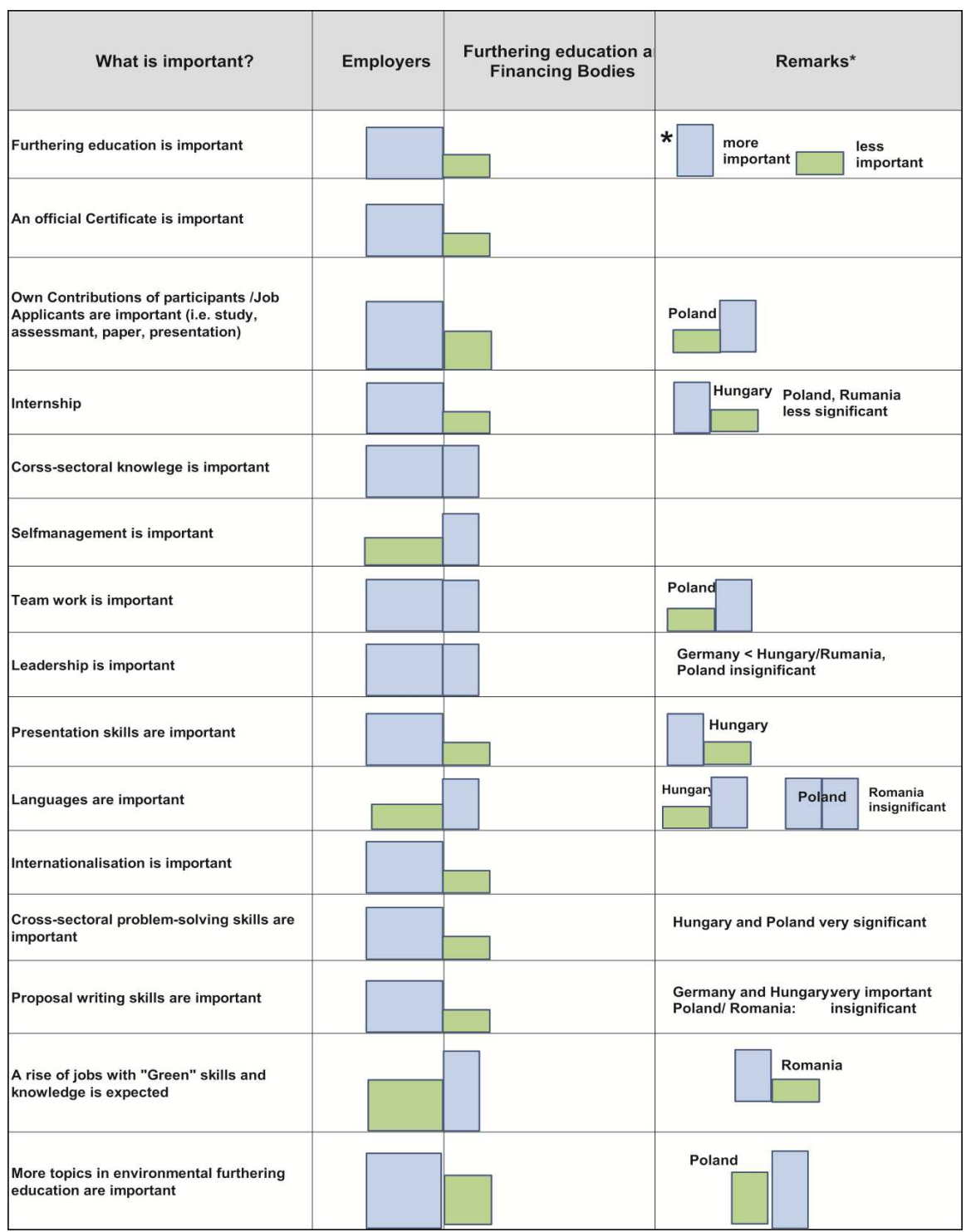

Fig. 4. Different assessments of employers and furthering education respondents. 


\section{Interpretation and future prospects}

The studies revealed differences in the job topics of the "green jobs" in the four countries. Some countries do not define "green" in jobs yet. However, the topics are similar, even if the ranking is somewhat different.

The questionnaire questions addressed the opinions of employers and furthering education / financing bodies as closely as possible. The objective was to find out if the answers were as similar, or if mismatches in the opinions were detected. In that case, the curriculum would have to be adapted to the commercial and labour market environments. The results showed significant country-specific differences and gaps between employer and furthering education provider/financing body respondents. Employers rate the following topics higher than the Education/Finance providers:

- General more furthering education is needed, in Hungary this gap is significantly large;

- Official certificate should be handed out;

- Own participant contributions, i.e. presentation, practical project work, study, assessment are favourable, not tests;

- Internship should be part of the course, favourably abroad in order to expose the participants to an international environment, strengthen their internationalization and in consequence their resilience;

- Cross-sector knowledge and project management is important for both respondent groups;

- Self-management is less important for the employers;

- Team work is valued rather equally, in Poland significantly lower in employers' estimates. Here the curriculum has to be adapted to nation-specific needs;

- Leadership seems less important among German employers, however, it is significantly higher in value for Hungarian and Romanian employers;

- Presentation techniques are very high in value for employers. In Hungary, this trend is significantly sharper than in the other countries;

- Languages are not as important for the employers as the furthering institutes rated;

- Internationality, plays a big role for all the employers;

- Cross-sector problem solving skills are rated very important among employers, with even stronger trend in Poland and Hungary;

- Proposal writing is significantly important among the employers in Germany, in Hungary even more sharply visible.

Employers in Germany are rather indifferent in predicting a rising number of green jobs in the future. Romania is the opposite: here the employers expect a sharp rise in green jobs. The Authors can only speculate the causes: maybe in German the green job machine is very well established and has not as much growing potential any more (being on a high level already), whereas in Romania, the green jobs are in an earlier stage.

All employers like more furthering education topics in the "green" job environment, however only Poland has similar opinions among the both respondent groups.

\section{Further actions}

Actions will be taken at all topics analyzed that are very important for the employers. The course design will put more emphasis on them, when fine tuning the curricula, also by adding new modules, if necessary. Most of the topics can be taken up and added in a short-time activity, and there will be "quick wins" for the fine-tuned curriculum with the knowledge of now.

A mid-term or even a long-term goal will be establishing official certificates, acknowledged in the partner states or even on a European scale. It acquires quality management audits, working with accreditation bodies, disseminating the curriculum and the 
actual study and questionnaire findings in order to make the course and the certificate accepted. Stakeholder consultation also plays a large role, and this takes time.

The study of job titles in the job data bases revealed a job ranking. In many jobs our planned course will give a contribution. The potential thematic course contributions with an adapted curriculum will cover topics such as: geologist, hydrogeologists, waste management, climate protection commissioner, agricultural ecologist, environmental management and planning, CR specialist (energy, sustainability) or sustainable tourism.

When dealing with business data, the practical application of the findings has to be kept in mind. For many market decisions it is not necessary to follow such a strict significance levels as in scientific literature. It is advisable to combine the data results with good judgment and experience.

The course programme will be implemented in a follow-up ERASMUS project and put into life $2019-2021$.

This research has been funded by the European Union, ERASMUS Plus funding Schmes (EUBILDUNAKLIM 2016-1-DE02-KA204-003254), which gratefully acknowledged.

\section{References}

1. Bureau of Labor Statistics, Washington, https://www.bls.gov/green/green_definition.htm (2013)

2. D.M. Kammen, \& D. Engel, Green Jobs and the Clean Economy; Copenhagen Climate Council, (2009), https:/antr.assembly.ca.gov/sites/antr.assembly.ca.gov/files/hearings/EngleKammenCopenhagenClimateConcill\%20-\%202009.pdf (20.09.2018)

3. V. Éri, Labor market impacts of environmentally conscious economic transformation, potentials of green jobs. Center of Environmental Studies, Budapest (2010)

4. UNEP, http://www.unepfi.org/about/

5. ILO: Guidelines for a just transition towards environmentally sustainable economies and societies for all (2016), www.ilo.org

6. ITUC, https://www.etuc.org/en

7. IEO, https://www.ioe-emp.org/

8. Biuletyn Mazowieckiego Obserwatorium Rynku Pracy (2015), (in Polish)

9. http:/hr.businesslive.ro/top-50-site-uri-de-job-uri-din-romania/ 